\title{
Restoration of hydrogenase activity in hydrogenase-negative strains of Escherichia coli by cloned DNA fragments from Chromatium vinosum and Proteus vulgaris
}

\author{
Alpana Chaudhuri and Alvin I. Krasna* \\ Department of Biochemistry and Molecular Biophysics, The Cancer Center/Institute for Cancer Research, College of \\ Physicians and Surgeons, Columbia University, New York, NY 10032, USA
}

(Received 1 September 1989; revised 29 January 1990; accepted 15 February 1990)

\begin{abstract}
DNA fragments from Proteus vulgaris and Chromatium vinosum were isolated which restored hydrogenase activities in both hydA and hydB mutant strains of Escherichia coli. The hydA and hydB genes, which map near minute 59 of the genome map, $17 \mathrm{~kb}$ distant from each other, are not structural hydrogenase genes, but mutation in either of these genes leads to failure to synthesize any of the hydrogenase isoenzymes. The smallest DNA fragments which restored hydrogenase activity to both $E$. coli mutant strains were $4.7 \mathrm{~kb}$ from $C$. vinosum and 2.3 $\mathrm{kb}$ from $P$. vulgaris. These fragments were cleaved into smaller fragments which did not complement either of the $E$. coli mutations. The cloned heterologous genes also restored formate hydrogenlyase activity but they did not restore activity in hydE, hup $A$ or hup $B$ mutant strains of $E$. coli. The cloned genes, on plasmids, did not lead to the synthesis of proteins of sufficient size to be the hydrogenase catalytic subunit. The hydrogenase proteins synthesized by $h y d A$ and $h y d B$ mutant strains of $E$. coli transformed by cloned genes from $P$. vulgaris and $C$. vinosum were shown by isoelectric and immunological methods to be $E$. coli hydrogenase. Thus, these genes are not hydrogenase structural genes.
\end{abstract}

\section{Introduction}

The synthesis of the enzyme hydrogenase in Escherichia coli requires a number of genes which have been characterized by mutational analysis. Four of these genes, $h y d A$, hydB, hydE and $h y d F$, have been mapped near minute 59 of the $E$. coli genome map and DNA fragments have been isolated which complemented the individual mutations (Lee et al., 1985; Sankar et al., 1985; Waugh \& Boxer, 1986; Chaudhuri \& Krasna, 1987; Sankar \& Shanmugam, 1988a, b). Strains with mutations in these genes are devoid of all hydrogenase activities (reduction of viologen dyes with $\mathrm{H}_{2}$, exchange reaction, growth on fumarate plus $\mathrm{H}_{2}$, evolution of $\mathrm{H}_{2}$ from formate) and lack the three hydrogenase isoenzymes (Ballantine \& Boxer, 1985; Sawers et al., 1985; Waugh \& Boxer, 1986). The genetic map of the hydrogenase genes near minute 59 is shown in Fig. 1 . The hyd $A$ and hydB genes are $17 \mathrm{~kb}$ distant from each other. The hydC and hydD genes, which map at minute 77 , are also required for synthesis of all three isoenzymes (Wu \&

Abbreviation: FHL, formate hydrogenlyase
Mandrand-Berthelot, 1986). Mutations in the hydC and $h y d E$ genes can be overcome by growing cells in the presence of high concentrations of nickel (Waugh \& Boxer, 1986; Wu \& Mandrand-Berthelot, 1986; Chaudhuri \& Krasna, 1987). The role of the hydA, hydB and $h y d F$ genes is not known. None of these genes are structural genes for hydrogenase but they are required for the synthesis of all hydrogenase isoenzymes.

To elucidate the role of the cloned $E$. coli hydrogenase genes near minute 59, DNA fragments were isolated from DNA libraries of hydrogenase-containing Chromatium vinosum and Proteus vulgaris and tested for their ability to restore the hydrogenase phenotype in hyd $A$ and hydB mutant strains of $E$. coli.

\section{Methods}

Organisms and growth conditions. Hydrogenase-positive $C$. vinosum and $P$. vulgaris were grown as previously described (Gitlitz \& Krasna, 1975; Schengrund \& Krasna, 1969) and the DNA isolated from these cells was used to prepare genomic libraries (Chaudhuri \& Krasna, 1987, 1988). The wild-type hydrogenase-positive $E$. coli strain was K12W6 met bio (ATCC 25019). The hydrogenase-negative $E$. coli strains were SE-31 (hydB) and SE-19-1 (hydA) (Lee et al., 1985), kindly supplied by 
Dr K. T. Shanmugam. As positive controls, the hydA strain was transformed by plasmid pSE-201 and the hydB strain by plasmid pSE-128 (Sankar et al., 1985).

Bacteria were grown in complex or minimal medium containing appropriate antibiotics when required for selection as described previously (Chaudhuri \& Krasna, 1987).

Enzyme assays. The enzyme activities of interest were measured at $25^{\circ} \mathrm{C}$ in washed cell suspensions. Hydrogenase activity was assayed by the deuterium exchange method and reduction of viologen dyes; formate hydrogenlyase (FHL) activity was determined by manometric measurements of evolution of $\mathrm{H}_{2}$ from formate as described previously (Chaudhuri \& Krasna, 1987).

Screening methods for hydrogenase. The symbols $\mathrm{Hyd}^{-}$and hyd designate the phenotype and genotype of cells that lack all demonstrable hydrogenase activity: exchange reaction, reduction of viologen dyes by $\mathrm{H}_{2}$, growth on fumarate plus $\mathrm{H}_{2}$ and evolution of $\mathrm{H}_{2}$ from formate. The details of the screening methods were described by Chaudhuri \& Krasna (1987) and are based on reduction of methyl viologen by $\mathrm{H}_{2}$ and growth on fumarate plus $\mathrm{H}_{2}$. Strains SE-31 (hydB) and $\mathrm{SE}-19-1$ (hydA) are $\mathrm{Hyd}^{-}$and become $\mathrm{Hyd}^{+}$when transformed by the cloned E. coli DNA fragments on plasmids (Sankar et al., 1985). The same screening methods were used when these strains were transformed by plasmid DNA libraries from $C$. vinosum or $P$. vulgaris. $\mathrm{Hyd}^{+}$transformants were then grown on minimal medium plus glucose or on fumarate plus $\mathrm{H}_{2}$ and assayed by deuterium exchange.

Preparation of and transformation by genomic DNA libraries. The methodology was essentially that described earlier (Chaudhuri \& Krasna, 1987) for the cloning of and transformation by an E. coli DNA library. Chromosomal DNA from $C$. vinosum or $P$. vulgaris was partially digested with the restriction enzyme Sau $3 \mathrm{~A}$, subjected to electrophoresis on $0.6 \%$ agarose, and fragments in the size range 4-20 $\mathrm{kb}$ isolated. These fragments were ligated to pBR322 which had been cleaved with BamHI and treated with calf intestinal phosphatase followed by purification by agarose electrophoresis. These plasmid libraries transformed $E$. coli strain CC114 with good efficiency (Chaudhuri \& Krasna, 1987) and all the transformed colonies were collected, grown in large volume and plasmid DNA isolated. These purified plasmid DNA preparations were the $C$. vinosum and $P$. vulgaris libraries used for gene selection.

These two libraries were used to transform hydA and hydB mutant strains of $E$. coli to ampicillin resistance $\left(\mathrm{Ap}^{\mathrm{R}}\right)$. A large number of these colonies were then grown on fumarate plus $\mathrm{H}_{2}$ to enrich for $\mathrm{Hyd}^{+}$cells. These cells were plated on agar and screened for the $\mathrm{Hyd}^{+}$phenotype. A number of positive isolates were selected, and DNA was prepared from each and used to transform the mutant strains to the $\mathrm{Hyd}^{+}$ phenotype. In each case all $\mathrm{Ap}^{\mathrm{R}}$ transformants were $\mathrm{Hyd}^{+}$by all criteria including high levels of deuterium exchange in cells grown on fumarate plus $\mathrm{H}_{2}$. The plasmids were mapped by restriction enzyme digestion. All the $\mathrm{Hyd}^{+}$transformants from the respective genomic libraries were identical.

Hybridization studies. The cloned plasmid DNA fragments isolated from the different organisms were treated with appropriate restriction enzymes and purified by agarose gel electrophoresis to obtain unique fragments from each plasmid (free of vector plasmid DNA) that could be used as probes for hybridization to other plasmid digests or to chromosomal DNA digested with $E c o$ RI. Hybridizations were carried out in $50 \%(\mathrm{v} / \mathrm{v})$ formamide at $42^{\circ} \mathrm{C}\left(T_{\mathrm{m}}-14^{\circ} \mathrm{C}\right)$ overnight with the denatured labelled probe and the filters were washed in $2 \times \mathrm{SSC} / 0.1 \%$ SDS at room temperature for $15 \mathrm{~min}$ and then at $65^{\circ} \mathrm{C}\left(T_{\mathrm{m}}-25^{\circ} \mathrm{C}\right)$ for $2 \mathrm{~h}$ with four changes of buffer $(1 \times \mathrm{SSC}$ is $0.15 \mathrm{M}-\mathrm{NaCl}, 0.015 \mathrm{M}$ trisodium citrate, $\mathrm{pH} 7 \cdot 0$ ). Autoradiography was used to locate the bands. Washing the filters at 50,37 or $25^{\circ} \mathrm{C}$ gave the same results as washing at $65^{\circ} \mathrm{C}$.
Synthesis of plasmid-coded proteins. The maxicell procedure of Sancar et al. (1979) was followed, using a mixture of ${ }^{14} \mathrm{C}$-labelled amino acids and ${ }^{35}$ S-labelled methionine. E. coli strain CSR603 (Sancar et al., 1979) was obtained from the $E$. coli Genetic Stock Center, Yale University.

Characterization of hydrogenase proteins. Membranes were isolated as previously described (Chaudhuri \& Krasna, 1988) from parental strains of $E$. coli, P. vulgaris and C. vinosum as well as from hydA and hydB mutant strains of $E$. coli (SE-31 and SE-19-1) transformed by the different plasmids. The membranes were solubilized with Triton or Lubrol, and analysed by isoelectric chromatofocusing between $\mathrm{pH} 4$ and pH 6 using Polybuffer PBE94 (Pharmacia). The solubilized membranes were also tested for reactivity with antibodies to $E$. coli hydrogenase isoenzyme 1 (Sawers et al., 1985). The antibodies were prepared by Dr K. T. Shanmugam and were a mixture of monoclonal antibodies to the separated $59 \mathrm{kDa}$ subunit and the $28 \mathrm{kDa}$ subunit. The membrane preparations were analysed by ELISA and by Western blotting. The proteins were treated with anti-hydrogenase 1 antibodies and then with anti-mouse-IgG antibodies conjugated with alkaline phosphatase and the colour developed with suitable substrates (Blake et al., 1984).

\section{Results and Discussion}

\section{Restoration of the $\mathrm{Hyd}^{+}$phenotype by a cloned DNA fragment from C. vinosum}

From the $C$. vinosum library a single plasmid was isolated which restored hydrogenase activity in both hydA and hydB mutant strains. The plasmid, pSE3-1Chr $(9 \cdot 6 \mathrm{~kb})$ had a chromosomal DNA insert of $5 \cdot 2 \mathrm{~kb}$; the restriction digest map is shown in Fig. 2. The results in Table 1 show that this plasmid restored deuterium exchange activity in both mutant strains. The deuterium exchange activity in the wild-type $E$. coli strain K12W6 was not affected by transformation by pSE3-1Chr. This plasmid did not restore activity to a hydE mutant strain of $E$. coli. An $E$. coli DNA fragment has been isolated (Waugh \& Boxer, 1986; Chaudhuri \& Krasna, 1987) which restored activity to both $h y d B$ and hydE mutant strains of E. coli. No DNA fragment from $E$. coli has been isolated which complements both hydA and hydB mutations. In E. coli the distance between these two genes is about $17 \mathrm{~kb}$, based on reported genetic maps near minute 59 (Yerkes et al., 1984; Karube et al., 1984; Sankar et al., 1985; Kohara et al., 1987).

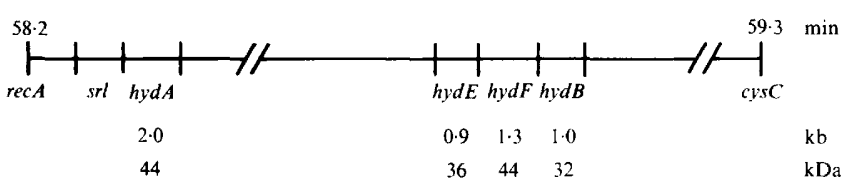

Fig. 1. Location of the hyd genes near minute 59 in the $E$. coli genome map. The subunit molecular masses $(\mathrm{kDa})$ of the protein products found in maxicells transformed with cloned DNA fragments are shown. The maximum size of each gene $(\mathrm{kb})$ is also shown. The figure was drawn from data presented by Sankar et al. (1985), Chaudhuri \& Krasna (1987) and Sankar \& Shanmugam (1988b), and in this paper. 


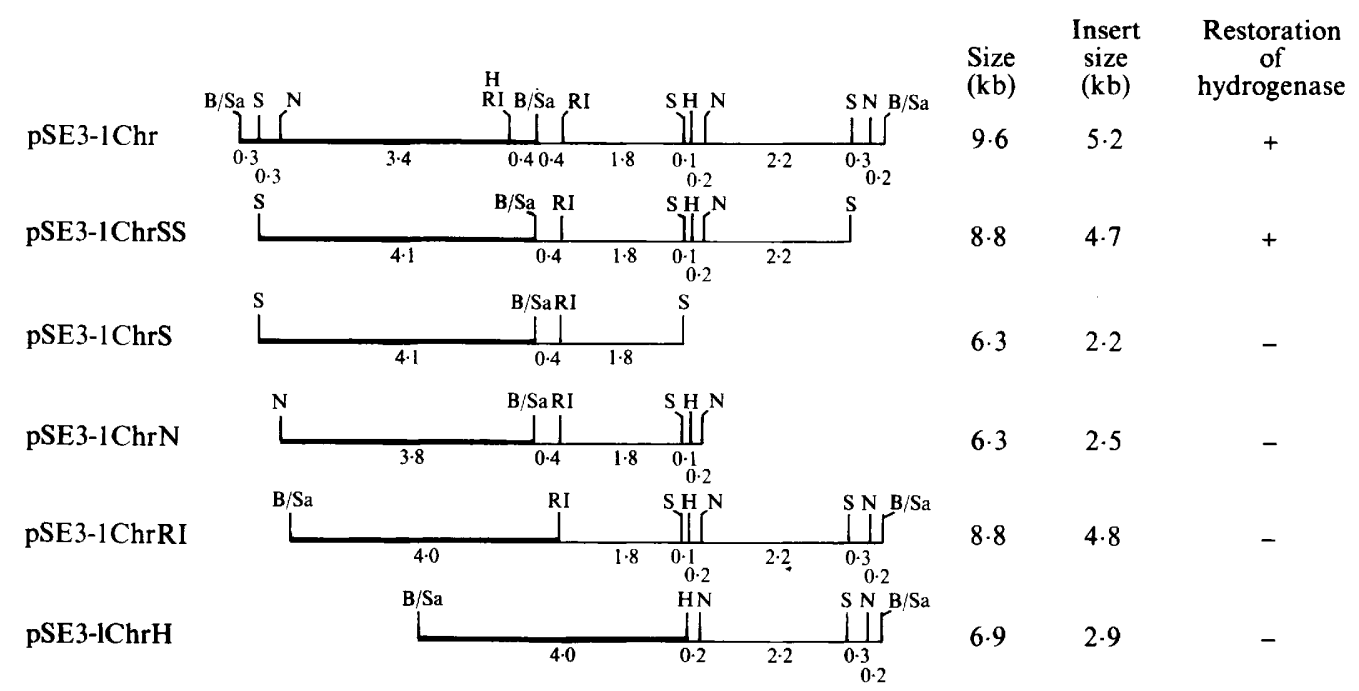

Fig. 2. Restriction digest maps of plasmids from C. vinosum. The circular plasmids are represented in linear form, the heavy line being the vector plasmid and the light line the chromosomal DNA insert. The numbers beneath the line indicate the size (kb) of the fragment between the two indicated restriction sites. The letters indicate the restriction sites: B/Sa, BamHI-Sau3A junction of vector and insert; H, HindIII; N, NruI; RI, EcoRI; S, Sall. There are no sites in the insert for ClaI, EcoRV, NdeI, NheI, PstI, PvuII, ScaI and SphI. The insert in pSE3-1Chr has one BaII site, one KpnI site, two AvaI sites, five StyI sites and five PvuI sites which have not been mapped precisely.

Table 1. Hydrogenase activity of E. coli mutant strains transformed by cloned DNA fragments

\begin{tabular}{|c|c|c|c|c|}
\hline \multirow[b]{2}{*}{$\begin{array}{l}\text { Recipient } \\
\text { strain }\end{array}$} & \multirow[b]{2}{*}{$\begin{array}{l}\text { hyd } \\
\text { genotype }\end{array}$} & \multirow[b]{2}{*}{ Plasmid } & \multicolumn{2}{|c|}{$\begin{array}{l}\text { Hydrogenase specific activity* } \\
\left.\text { [units (mg protein })^{-1}\right]\end{array}$} \\
\hline & & & $\begin{array}{l}\text { Glucose } \\
\text { grown }\end{array}$ & $\begin{array}{c}\text { Fumarate }+\mathrm{H}_{2} \\
\text { grown }\end{array}$ \\
\hline K12W6 & Wild-type & None & 0.7 & $4 \cdot 8$ \\
\hline $\begin{array}{l}\text { SE-31 } \\
\text { SE-31 }\end{array}$ & $\begin{array}{l}\text { hydB } \\
\text { hydB }\end{array}$ & $\begin{array}{l}\text { None } \\
\text { pSE3-1Chr }\end{array}$ & $\begin{array}{r}<0.02 \\
0.56\end{array}$ & $\begin{array}{l}\text { NG } \\
4 \cdot 6\end{array}$ \\
\hline SE-19-1 & hydA & None & $<0.02$ & NG \\
\hline SE-19-1 & hydA & pSE3-1Chr & $0 \cdot 38$ & $4 \cdot 4$ \\
\hline SE-31 & hydB & pSE3-1PV & $0 \cdot 33$ & $3 \cdot 7$ \\
\hline SE-19-1 & hydA & pSE3-1PV & 0.73 & $4 \cdot 4$ \\
\hline SE-31 & hydB & pSE3-1 PVSp & $0 \cdot 3$ & $4 \cdot 0$ \\
\hline SE-19-1 & hydA & pSE3-1PVSp & $0 \cdot 4$ & $4 \cdot 7$ \\
\hline
\end{tabular}

NG, No growth.

*A unit of activity is defined as the appearance of $0.1 \%{ }^{2} \mathrm{H}^{1} \mathrm{H} \mathrm{h}^{-1}$ in the gas phase from $10 \%{ }^{2} \mathrm{H}_{2} \mathrm{O}$ and is equivalent to reaction with 0.287 $\mu \mathrm{mol} \mathrm{H}_{2} \min ^{-1}$. These values are the mean of two separate determinations with different samples of intact cells. The maximum deviation from the mean was $\pm 10 \%$.

A single plasmid complementing both hydA and hydB mutations could be due to the plasmid containing both the individual hydA and hydB genes from $C$. vinosum which are homologous to those in $E$. coli. To decide whether pSE3-1Chr contained individual hydA and hydB genes, the plasmid was subcloned into smaller fragments by restriction enzyme digestion of the plasmid and self- ligation (Fig. 2). Removal of the $0.5 \mathrm{~kb}$ fragment at the right of the insert gave a plasmid with a $4.7 \mathrm{~kb}$ insert (pSE3-1ChrSS) which was as active as the original plasmid in restoring activity in both hydA and hydB mutant strains. The $2 \cdot 2-2.5 \mathrm{~kb}$ insert at the left of the fragment (pSE3-1ChrS and pSE3-1ChrN) and the $2.9 \mathrm{~kb}$ insert at the right of the fragment (pSE3-1ChrH) failed to complement either the hydA or the hydB mutant strain, suggesting that the original $4.7 \mathrm{~kb}$ DNA fragment did not contain independently active hydA and $h y d B$ genes. Removal of the $0.4 \mathrm{~kb}$ fragment at the extreme left of the original insert (pSE3-1ChrRI) led to the loss of complementation for both hydA and hydB mutant strains. It is possible that the $0.4 \mathrm{~kb} B a m \mathrm{HI} / S a u 3 \mathrm{~A}-E c o \mathrm{RI}$ insert fragment contains a single promoter for two genes with the first gene extending past the first $\mathrm{NruI}$ site.

The smallest active DNA fragment, $4.7 \mathrm{~kb}$, could code for a protein of molecular mass $157 \mathrm{kDa}$; this is sufficiently large to be the hydrogenase protein, which was reported to be a dimer of two $50 \mathrm{kDa}$ subunits (Gitlitz \& Krasna, 1975). Sawers \& Boxer (1986) reported that the subunit molecular masses of hydrogenase isoenzyme 1 were 64 and $35 \mathrm{kDa}$, and Ballantine \& Boxer (1986) found that the subunit molecular masses of isoenzyme 2 were 61 and $35 \mathrm{kDa}$. The catalytic subunit was the one of higher molecular mass (Harker et al., 1986). It is, of course, possible that the DNA fragment cloned is a gene or genes whose effect in $E$. coli is the same as the combined effect of the individual hydA and hydB genes. This will be further discussed below. 


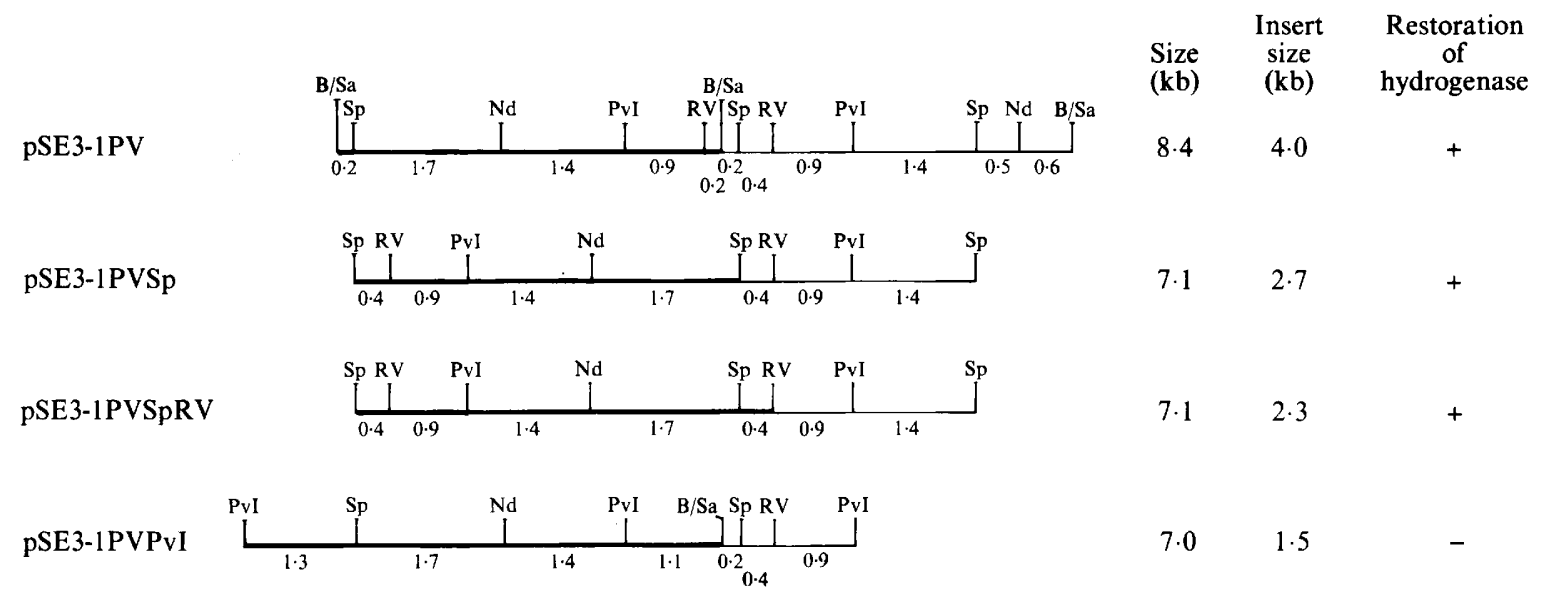

Fig. 3. Restriction digest maps of plasmids from P. vulgaris. The restriction sites and their abbreviations are: B/Sa, BamHI-Sau3A junction of insert and vector; Nd, NdeI; PvI, PvuI ; RV, EcoRV; Sp, SphI. There are no sites in the insert for AvaI, BaII, ClaI, EcoRI, HindIII, KpnI, NheI, NruI, PstI, PvuII, SaII, ScaI and StyI.

\section{Restoration of the Hyd $d^{+}$phenotype by a cloned DNA} fragment from $P$. vulgaris

From the $P$. vulgaris library a single plasmid was isolated which restored hydrogenase activity in both hydA and hydB mutant strains. The plasmid, pSE3-1PV $(8 \cdot 4 \mathrm{~kb})$ had a chromosomal DNA insert of $4.0 \mathrm{~kb}$; the restriction digest map is shown in Fig. 3. The results in Table 1 demonstrate that this plasmid restored deuterium exchange activity in both mutant strains. The activity in $E$. coli strain K12W6 (wild-type) was not affected by the $P$. vulgaris plasmid and this plasmid did not restore activity to a hydE mutant strain of $E$. coli.

The plasmid was subcloned into smaller fragments by restriction enzyme digestion, purification of the fragment of interest, and ligation to pBR322 treated with the same restriction enzyme. Treatment of pSE3-1PVSp with $E c o R V$ gave a $2.7 \mathrm{~kb}$ fragment containing the $0.4 \mathrm{~kb}$ SphI-EcoRV fragment of pBR322. Treatment of pSE3-1 PV with $P v u$ I gave a $2.6 \mathrm{~kb}$ fragment containing the $1.1 \mathrm{~kb}$ PvuI-BamHI/Sau3A fragment of pBR322. Ligation of these fragments to pBR322 cut with EcoRV or $P v u \mathrm{I}$ gave plasmids containing a repeat of $0.4 \mathrm{~kb}$ or $1.1 \mathrm{~kb}$ pBR322 fragment, respectively.

The restriction maps of the subclones are shown in Fig. 3. The 2.7 kb SphI-SphI insert (pSE3-1 PVSp) was as active as the $4.0 \mathrm{~kb}$ insert in restoring activity in both hydA and hydB mutant strains (see Table 1). Removal of a $0.4 \mathrm{~kb}$ fragment at the left of this insert (pSE31PVSpRV) did not affect the complementation. Removal of the $2.5 \mathrm{~kb}$ DNA fragment at the right of the original insert (pSE3-1PVPvI) led to the loss of all activities. The smallest active DNA fragment, $2 \cdot 3 \mathrm{~kb}$, could code for a protein of molecular mass $77 \mathrm{kDa}$. The native molecular mass of the $P$. vulgaris hydrogenase was reported to be $115 \mathrm{kDa}$ (Schengrund \& Krasna, 1969); the subunit composition has not been determined.

\section{Hybridization studies}

To determine whether the cloned DNA fragments from $C$. vinosum and $P$. vulgaris which restored hydrogenase activity to both $h y d A$ and $h y d B$ mutant strains of $E$. coli contained individual hydA or $h y d B$ genes homologous to those of $E$. coli, Southern blot hybridizations were carried out among the different plasmids as well as to chromosomal DNA digests of the three organisms of interest (see Methods for details). [The restriction digest maps of hyd $A$ and $h y d B$ are given by Sankar et al. (1985) and the map of $h y d E$ by Chaudhuri \& Krasna (1987).] The results are summarized in Table 2 . The $E$. coli hydB probe did not hybridize to the $E$. coli hydA probe nor to plasmids pSE3-1Chr or pSE3-1PV. It only hybridized to $E$. coli chromosomal DNA. The E. coli hydA probe did not hybridize to plasmids pSE3-1Chr or pSE3-1PV; it only hybridized to $E$. coli chromosomal DNA. A probe prepared from plasmid pSE3-1PV (2.7 kb $S p h \mathrm{I}-S p h \mathrm{I}$ fragment) did not hybridize to pSE3-1Chr and only hybridized to $P$. vulgaris chromosomal DNA. Plasmid pSE3-1Chr only hybridized to C. vinosum chromosomal DNA. None of these plasmids hybridized to the cloned hydE gene (Chaudhuri \& Krasna, 1987) or hupB gene (Chaudhuri \& Krasna, 1988).

It is clear that the cloned DNA fragments from $C$. vinosum and $P$. vulgaris which complement $E$. coli strains with mutations in hydA and hydB did not hybridize to each other, nor to the cloned $E$. coli hydA and $h y d B$ genes, 
Table 2. Southern hybridization among different DNA fragments

\begin{tabular}{|c|c|c|c|c|c|c|c|}
\hline \multirow[b]{2}{*}{ Probe } & \multicolumn{7}{|c|}{ Hybridization* to restriction-enzyme-digested DNA from: } \\
\hline & pSE-130 & pSE-201 & pSE3-1PV & pSE3-1Chr & E. coli & P. vulgaris & C. vinosum \\
\hline E. coli hydB† & + & - & - & - & + & - & - \\
\hline E. coli hydA $A_{+}^{+}$ & - & + & - & - & + & - & - \\
\hline P. vulgaris hyd $A B \S$ & - & - & + & - & - & + & - \\
\hline pSE3-1Chr & ND & ND & ND & + & - & - & + \\
\hline
\end{tabular}

$*+$, Good hybridization under the conditions outlined in Methods; - , no hybridization; ND, not done.

$+2.8 \mathrm{~kb}$ SalI-Sall fragment from plasmid pSE-130 (hydB).

$\$ 3.9 \mathrm{~kb}$ EcoRI-PstI fragment from plasmid pSE-201 (hydA).

$\S 2.7 \mathrm{~kb} S p h \mathrm{I}-S p h \mathrm{I}$ fragment from plasmid pSE3-1PV (hydAB).

and it is unlikely that they are simply carrying individual genes homologous to hydA and hydB genes. The cloned genes could be structural genes for hydrogenase or genes whose effect on $E$. coli is the same as the combined effect of hydA and hydB genes, though there is no strong homology in the DNA sequences.

\section{Restoration of FHL activity}

hydA and hydB mutant strains of $E$. coli lack all hydrogenase isoenzymes and are devoid of FHL activity, which has been ascribed to isoenzyme 3 (Ballantine \& Boxer, 1985; Sawers et al., 1985). The transformants described above were assayed for FHL activity (Table 3). Plasmids pSE-128 and pSE-201 contain cloned E. coli hydB and hydA genes (Sankar et al., 1985) and serve as controls for the restoration of FHL activity in the two mutant strains. The $P$. vulgaris plasmid, pSE3-1PV, restored FHL activity in both mutant strains, whereas the $C$. vinosum plasmid, $\mathrm{pSE} 3-1 \mathrm{Chr}$, restored $\mathrm{FHL}$ activity in the hydB mutant but not in the hydA mutant.

\section{Lack of complementation of Hup ${ }^{-}$mutants}

Hup $^{-}$mutant strains of E. coli show a hydrogen-uptakenegative phenotype (failure to reduce viologen dyes with $\mathrm{H}_{2}$ and to grow on fumarate plus $\mathrm{H}_{2}$ ), but express normal hydrogenase activity as measured by the deuterium exchange reaction. The cloned DNA fragments from $C$. vinosum or $P$. vulgaris did not complement hupA mutations at minute 65 (Lee et al., 1985) or hupB mutations at minute 17 (Chaudhuri \& Krasna, 1988) (data not shown).

\section{Synthesis of plasmid-encoded proteins}

Since the molecular masses of the polypeptides encoded by the $P$. vulgaris and $C$. vinosum plasmids might indicate whether the cloned genes were structural genes, the
Table 3. FHL activity in mutant strains transformed by plasmids

\begin{tabular}{lllc}
\hline \hline $\begin{array}{c}\text { Recipient } \\
\text { strain }\end{array}$ & $\begin{array}{c}\text { hyd } \\
\text { genotype }\end{array}$ & Plasmid & $\begin{array}{c}\text { FHL activity* } \\
\text { [nmol } \mathrm{H}_{2} \text { evolved } \\
\mathrm{min}^{-1} \text { (mg protein) }^{-1} \text { ] }\end{array}$ \\
\hline K12W6 & Wild-type & None & 42 \\
SE-31 & hydB & None & 0 \\
SE-31 & hydB & pSE-128 & 154 \\
SE-31 & hydB & pSE3-1Chr & 94 \\
SE-31 & hydB & pSE3-1PV & 116 \\
SE-19-1 & hydA & None & 0 \\
SE-19-1 & hydA & pSE-201 & 94 \\
SE-19-1 & hydA & pSE3-1Chr & 10 \\
SE-19-1 & hydA & pSE3-1PV & 148 \\
\hline \hline
\end{tabular}

* These values are the mean of two separate determinations with different samples of intact cells. The maximum deviation from the mean was $\pm 10 \%$.

maxicell procedure of Sancar et al. (1979) was used to identify the subunit molecular masses of these polypeptides. We had previously shown (Chaudhuri \& Krasna, 1987) that a plasmid containing the $E$. coli hydB, hydE and $h y d F$ genes led to the synthesis of polypeptides of molecular masses 41,36 and $30 \mathrm{kDa}$, the $36 \mathrm{kDa}$ protein being the product of $h y d \mathrm{E}$. Sankar \& Shanmugan (1988a, b) identified the $30 \mathrm{kDa}$ protein as the product of the $h y d B$ gene and the $41 \mathrm{kDa}$ protein as the product of the $h y d F$ gene.

Fig. 4 shows the maxicell results for the plasmids used in the present study. The plasmid vector, pBR322, coded for three polypeptides of molecular masses 43,33 , and 28 $\mathrm{kDa}$ (Sancar et al., 1979); the former two were seen only in longer exposures. Plasmid pSE-201, containing the hydA gene, led to the synthesis of a protein of subunit molecular mass $44 \mathrm{kDa}$. Plasmid pSE-128, used as the source of the hydB gene, led to the synthesis of proteins of molecular masses 72 and $78 \mathrm{kDa}$. (The $30 \mathrm{kDa}$ protein product of the hydB gene was not discernible in this 


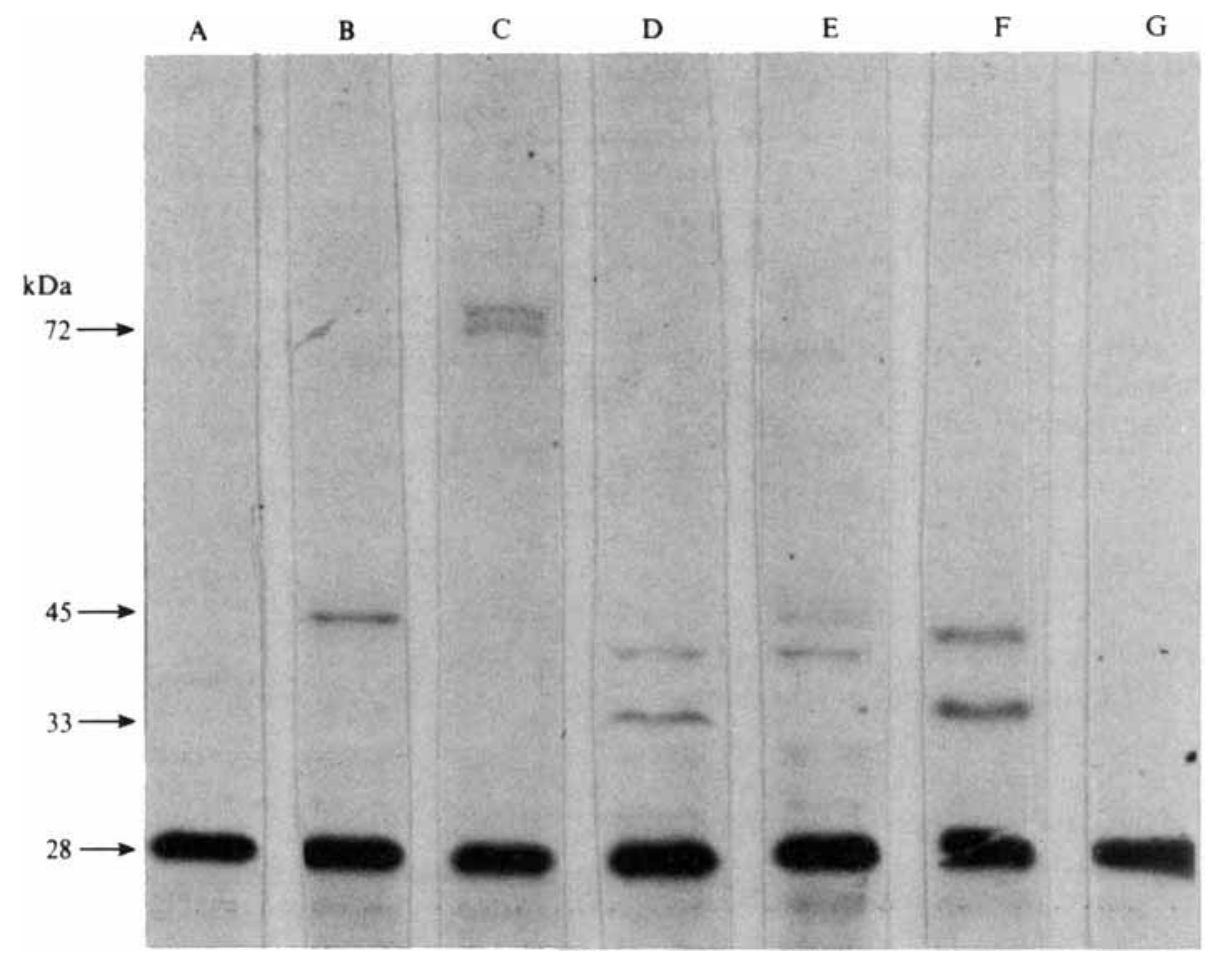

Fig. 4. Autoradiograph of an SDS-polyacrylamide gel of polypeptides expressed in maxicells (E. coli CSR603) by plasmids derived from E. coli, P. vulgaris and $C$. vinosum, A, pBR322; B, pSE-201; C, pSE-128; D, pSE3-1Chr; E, pSE3-1ChrSS; F, pSE3-1PV; G, pSE3IPVSpRV.

experiment.) Sankar et al. (1988) reported that the 72 and $78 \mathrm{kDa}$ proteins were products of the $f d v$ and $f h l A$ genes. Plasmid pSE3-1Chr led to the synthesis of polypeptides of molecular masses 33,38 and $44 \mathrm{kDa}$ (the last seen only in longer exposures) while the smaller plasmid pSE3$1 \mathrm{ChrSS}$ led to the synthesis of proteins of molecular masses 38 and $44 \mathrm{kDa}$. Plasmid pSE3-1PV led to the synthesis of polypeptides of molecular masses 33 and $40 \mathrm{kDa}$ and the smaller plasmid pSE3-1PVSpRV led to the synthesis of polypeptides of the same molecular masses (seen only in longer exposures).

\section{Characterization of hydrogenase in mutant strains transformed by plasmids}

If the hydrogenase genes isolated from $P$. vulgaris and $C$. vinosum are genes which restore the ability of hydA and hydB mutant strains of $E$. coli to synthesize the hydrogenase isoenzymes, then the enzymes synthesized should be characteristic of those of E. coli. On the other hand, if the cloned genes are structural genes, then the hydrogenases synthesized should be characteristic of those found in $P$. vulgaris or $C$. vinosum. The active enzymes synthesized by the mutant $E$. coli strains transformed by the cloned genes from the two heterologous organisms were thus studied in detail.
Solubilized membranes were prepared from wild-type $P$. vulgaris, C. vinosum and E. coli, and from hydA and hydB mutant strains of $E$. coli transformed by plasmids pSE3-1PV and pSE3-1Chr; the preparations were analysed by isoelectric chromatofocusing and reactivity with antibodies to $E$. coli hydrogenase isoenzymes. On isoelectric chromatofocusing most of the hydrogenase preparations had $\mathrm{pI}$ values of $5 \cdot 1-5 \cdot 3$, the only exception being the enzyme from $C$. vinosum which had a pI value of $4 \cdot 5-4 \cdot 7$. This would suggest that the $E$. coli mutant strains transformed by plasmid pSE3-1Chr synthesize $E$. coli hydrogenases.

Sawers et al. (1985) and Ballantine \& Boxer (1985) showed that $E$. coli has at least two hydrogenase isoenzymes and that antibodies to the individual isoenzymes do not cross-react with the different isoenzymes. To conclusively demonstrate that the hydrogenase protein synthesized in $E$. coli mutants transformed by the cloned genes from $P$. vulgaris and $C$. vinosum is $E$. coli hydrogenase, the solubilized membranes were tested for reactivity with antibodies to $E$. coli hydrogenase 1 . The results from a Western blot are shown in Fig. 5; similar results were obtained by ELISA methods. The hydB mutant strain does not react with the antibodies (data not shown). The hydrogenase from $P$. vulgaris cross-reacts with antibodies to the $E$. coli hydrogenase as does the $E$. 


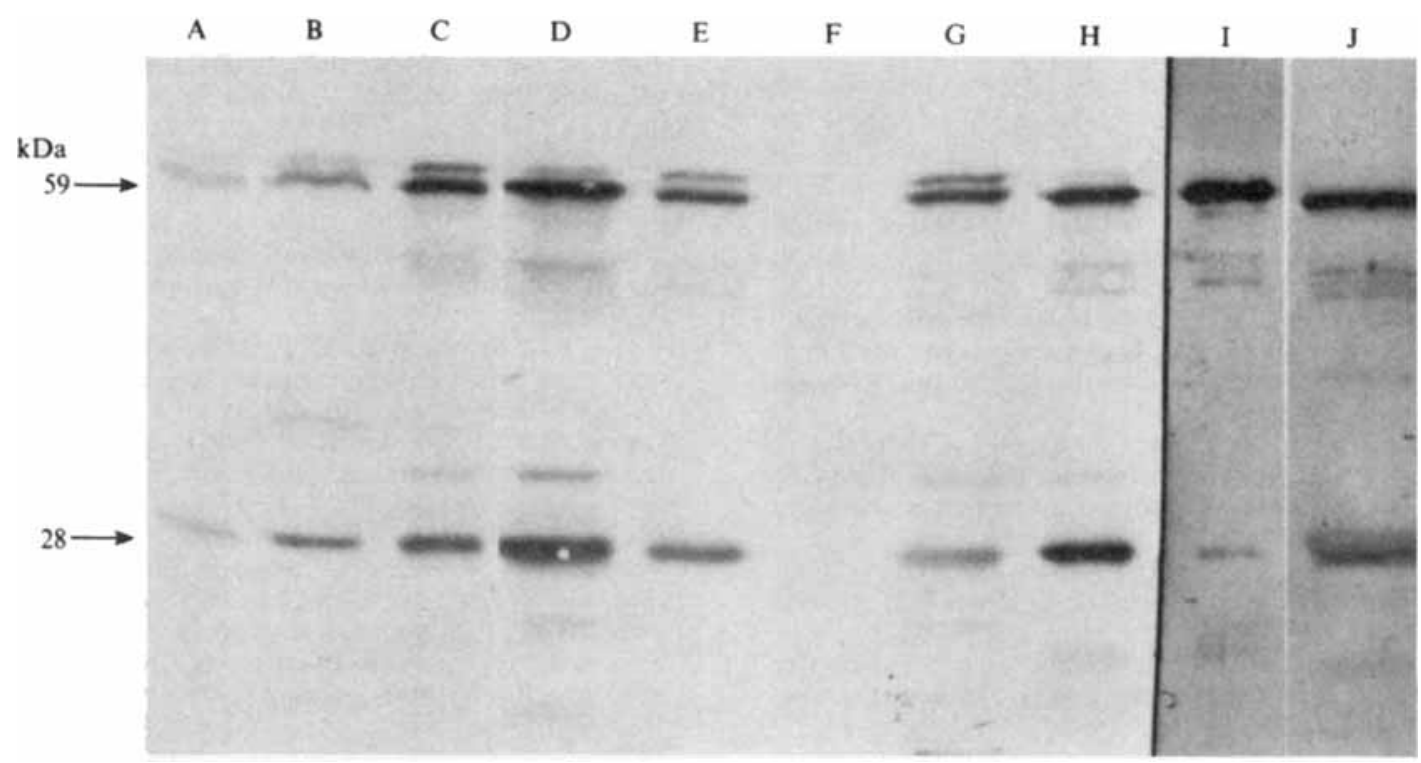

Fig. 5. Western blot of solubilized membrane preparations with antibodies to E. coli anti-hydrogenase 1. A and B, E. coli strain SE-31 (hydB) transformed by plasmid pSE-128 (A, Lubrol solubilized; B, Triton solubilized); C. P. vulgaris solubilized with Lubrol; D and E, E. coli strain SE-31 transformed by plasmid pSE3-1PV (D, Lubrol solubilized; E, Triton solubilized); F. C. vinosum solubilized with Lubrol; G and H, E. coli strain SE-31 transformed by plasmid pSE3-1Chr (G, Lubrol solubilized; H, Triton solubilized); I, purified $E$. coli hydrogenase 1; J, wild-type E. coli cells. Sample A, $10 \mu \mathrm{g}$; B and F, $5 \mu \mathrm{g}$; all others $2 \mu \mathrm{g}$.

coli hydB mutant transformed by the $P$. vulgaris cloned DNA fragment. Thus, no definite conclusion can be drawn as to the nature of the hydrogenase synthesized by the $E$. coli mutant strain transformed by the $P$. vulgaris DNA fragment. However, from the data presented above on the restoration of all hydrogenase activities, and the relatively small size of the proteins encoded by the $P$. vulgaris DNA fragment, it seems probable that the hydrogenase protein synthesized by the $E$. coli hydB mutant transformed by the $P$. vulgaris DNA fragment is E. coli hydrogenase.

It is also clear from Fig. 5 that the proteins in $C$. vinosum do not cross-react with antibodies to $E$. coli hydrogenase 1 while the $E$. coli hydB mutant transformed by the cloned DNA fragment from $C$. vinosum synthesizes $E$. coli hydrogenase 1. This demonstrates conclusively that the cloned DNA fragment is not a structural hydrogenase gene of $C$. vinosum.

\section{Concluding remarks}

This study has shown that DNA fragments from $P$. vulgaris and $C$. vinosum (which do not hybridize to each other) restore activity to two distinct mutant strains of $E$. coli (hyd $A$ and $h y d B$ ) with mutant genes $17 \mathrm{~kb}$ distant from each other. The individual hydA and hydB genes have been shown to be required for the synthesis of all hydrogenase isoenzymes in E. coli. It was also demonstrated that the two heterologous DNA fragments do not contain individual hydA and $h y d B$ genes homologous to those of $E$. coli. Rather they contain a gene (or genes) whose protein product (or products) in E. coli has the same positive effect as the combined effects of the products of the $E$. coli hydA and hydB genes. The precise mechanism of this effect is not known, but it is likely that both the hyd $A$ and $h y d B$ gene products (as well as those of the genes cloned from $P$. vulgaris and $C$. vinosum) affect another gene or genes which lead to synthesis of all hydrogenase isoenzymes. A similar conclusion was arrived at by Sankar \& Shanmugam $(1988 b)$ with regard to the $E$. coli hydF and $f h l A$ genes.

DNA fragments from Clostridium butyricum and Citrobacter freundii have been shown to complement $E$. coli hydA mutations (Karube et al., 1983; Kanayama et al., 1986). In the former case the DNA fragment hybridized to $E$. coli DNA and in the latter case hybridization results were not reported.

Note added in proof

It has recently been demonstrated in this laboratory that plasmids pSE3-1Chr and pSE3-1PV also restore all hydrogenase activities in a hydF mutant strain of E. coli (Sankar \& Shanmugam, 1988b). These plasmids, however, do not restore formate hydrogenlyase activity in a $f h l A$ mutant strain of $E$. coli (Sankar et al., 1988). The position of the $h y d F$ gene, immediately to the left of the hydB gene, is shown in Fig. 1. The $f h l A$ gene $(2 \mathrm{~kb})$ lies immediately to the right of the $h y d B$ gene.

This research was supported by the US Department of Energy Grant no. DE-FG02-85ER13374 and a Biomedical Research Support Grant from the National Institutes of Health. However, any opinions, finding, conclusions or recommendations expressed herein are those of 
the authors and do not necessarily reflect the view of the DOE or the NIH.

\section{References}

Ballantine, S. P. \& Boxer, D. H. (1985). Nickel-containing hydrogenase isoenzymes from anaerobically grown Escherichia coli K12. Journal of Bacteriology 163, 454-459.

Ballantine, S. P. \& BoXer, D. H. (1986). Isolation and characterization of a soluble active fragment of hydrogenase isoenzyme 2 from the membranes of anaerobically grown Escherichia coli. European Journal of Biochemistry 156, 277-284.

Blake, M. S., Johnston, K. H., Russell-Jones, G. J. \& GotsChlich E. C. (1984). A rapid, sensitive method for detection of alkaline phosphatase-conjugated anti-antibody on western blots. Analytical Biochemistry 136, 175-179.

Chaudhuri, A. \& KraSNA, A. I. (1987). Isolation of genes required for hydrogenase synthesis in Escherichia coli. Journal of General Microbiology 133, 3289-3298.

ChaUdHURI, A. \& KRASNA, A. I. (1988). Isolation of a gene required for growth of Escherichia coli on fumarate and $\mathrm{H}_{2}$. Journal of General Microbiology 134, 2155-2164.

GiTliTZ, P. \& KRASNA, A. I. (1975). Structural and catalytic properties of hydrogenase from Chromatium. Biochemistry 14, 2561-2568.

HARKeR, A. R., Zuber, M. \& Evans, H. J. (1986). Immunological homology between the membrane-bound hydrogenase of Rhizobium japonicum and Escherichia coli. Journal of Bacteriology 165, 579-584.

Kanayama, H., Urano, N., Aihara, C. \& Karube, I. (1986). Cloning and expression of Citrobacter freundii hydrogenase genes in Escherichia coli. Applied Microbiology and Biotechnology 24, 392-396.

Karube, I., Urano, N., Yamada, T., HirochiKa, H. \& SaKaguchi, K. (1983). Cloning and expression of the hydrogenase gene from Clostridium butyricum in Escherichia coli. FEBS Letters 158, 119-122.

KaRUBE, I., TOMiYAMA, A. \& KIKUCHI, A. (1984). Molecular cloning and physical mapping of the hyd gene of Escherichia coli $\mathrm{K}-12$. FEMS Microbiology Letters 25, 165-168.

KoHARA, Y., KiYotaKa, A. \& Katsumi, I. (1987). The physical map of the whole $E$. coli chromosome; application of a new strategy for rapid analysis and sorting of a large genomic library. Cell 50, 495-508.
Lee, J. H., Patel, P., Sankar, P. \& Shanmugam, K. T. (1985). Isolation and characterization of mutant strains of Escherichia coli altered in $\mathrm{H}_{2}$ metabolism. Journal of Bacteriology 162, 344-352.

SANCAR, A., Hack, A. M. \& RUPP, W. D. (1979). Simple method for identification of plasmid-coded proteins. Journal of Bacteriology 137, 692-693.

Sankar, P., Lee, J. H. \& Shanmugam, K. T. (1985). Cloning of hydrogenase genes and fine structure analysis of an operon essential for $\mathrm{H}_{2}$ metabolism in Escherichia coli. Journal of Bacteriology 162 , 353-360.

Sankar, P. \& Shanmugam, K. T. (1988a). Biochemical and genetic analysis of hydrogen metabolism in Escherichia coli : the hydB gene. Journal of Bacteriology 170, 5433-5439.

Sankar, P. \& Shanmugam, K. T. (1988b). Hydrogen metabolism in Escherichia coli: biochemical and genetic evidence for a hydF gene. Journal of Bacteriology 170, 5446-5451.

Sankar, P., Lee, J. H. \& Shanmugam, K. T. (1988). Gene-product relationships of $f h l$ and $f d v$ genes of Escherichia coli. Journal of Bacteriology 170, 5440-5445.

Sawers, R. G., Ballantine, S. P. \& Boxer, D. H. (1985). Differential expression of hydrogenase isoenzymes in Escherichia coli $\mathrm{K} 12$ : evidence for a third isoenzyme. Journal of Bacteriology 164, 1324-1331.

SAwERs, R. G. \& BoXer, D. H. (1986). Purification and properties of membrane-bound hydrogenase isoenzyme 1 from anaerobically grown Escherichia coli K12. European Journal of Biochemistry 156 , 265-275.

Schengrund, C. \& Krasna, A. I. (1969). Purification and properties of the light-activated hydrogenase of Proteus vulgaris. Biochimica et Biophysica Acta 185, 332-337.

WAUGH, R. \& BoXER, D. H. (1986). Pleiotropic hydrogenase mutants of Escherichia coli $\mathrm{K} 12$ : growth in the presence of nickel can restore hydrogenase activity. Biochimie 68, 157-166.

Wu, L. F. \& MANDRAND-BerThelot, M.-A. (1986). Genetic and physiological characterization of new Escherichia coli mutants impaired in hydrogenase activity. Biochimie 68, 167-179.

Yerkes, J. H., Casson, L. P., Honkanen, A. K. \& Walker, G. C. (1984). Anaerobiosis induces expression of ant, a new Escherichia coli locus with a role in anaerobic electron transport. Journal of Bacteriology 158, 180-186. 